\title{
PERTUMBUHAN DAN HASIL PANEN TANAMAN JAGUNG (Zea mays) VARIETAS LOKAL DAN HIBRIDA YANG DI INFEKSI CENDAWAN Fusarium sp
}

\author{
D.A.Trifatmawati ${ }^{1)}$ dan T.Sopandi ${ }^{2)}$ \\ 1) Mahasiswa Prodi Biologi FMIPA Universitas PGRI Adi Buana Surabaya \\ 2) Staf Pengajar Prodi Biologi FMIPA Universitas PGRI Adi Buana Surabaya \\ E-mail: ${ }^{1)}$ diyahayu020@gmail.com
}

\begin{abstract}
The aim of this study to prove the effect of Fusarium $s p$ fungus infection on corn (Zea mays) to the growth and yield of local corn varieties and hybrid corn varieties. After the age of 45 HST treatment done 5 polybags of plants local corn varieties and 5 polybags of plant hybrid corn varieties infected with Fusarium $s p$ fungus and 5 polybags of plants local corn varieties and 5 polybags of plant hybrid corn varieties not infected by fungus Fusarium sp. The result showed that treatment infected of Fusarium $s p$ and without Fusarium $s p$ fungus significant $(\mathrm{P}<0,05)$ to growth and yield of local varieties and hybrid varieties of corn. The average height of local varieties and hybrid varieties of corn with infected by Fusarium $s p$ significant $(\mathrm{P}<0.05)$ was lower than the height of corn without Fusarium $s p$ fungus. Local and hybrid varieties of corn after being infected with Fusarium $s p$ fungus showed results significant of leaf with. The yield of corn and the weight of kernel that has been shell showed treatment of Fusarium sp (F5) fungus significant $(\mathrm{P}<0,05)$ was lower than the yield of corn not infected by Fusarium sp. The results of this study can be concluded that infections of Fusarium $s p$ fungus on local varieties and hybrid varieties have an influence on growth and yield.
\end{abstract}

Keyword : Corn, Fusarium sp, growth and yield

\section{PENDAHULUAN}

Jagung merupakan makanan pokok kedua setelah padi untuk masyarakat Indonesia, karena memiliki kandungan gizi seperti karbohidrat dan protein. Secara lebih terinci kandungan gizi yang terdapat pada jagung meliputi pati (72-73\%), kadar gula sederhana jagung (glukosa, fruktosa, dan sukrosa) berkisarantara 1-3\%. Protein jagung (8-11\%) terdiri atas lima fraksi, yaitu: albumin, globulin, prolamin, glutelin, dan nitrogen nonprotein (Suarni dan Widowati, 2012). Jagung banyak dikembangkan di Indonesia untuk digunakan sebagai bahan makanan, pakan ternak dan bahan baku industry. Jagung merupakan salah satu tanaman serealia yang banyak dibudidayakan di berbagai daerah di Indonesia karena memiliki kegunaan yang cukup beragam dan kesesuaian lingkungan tumbuh dengan mayoritas kondisi lingkungan di Indonesia (Adisarwanto dan Widyastuti, 2000). 
Menurut Pusat Data dan Informasi Pertanian kebutuhan jagung di Indonesia untuk pemenuhan konsumsi dan industri sebesar 15,75 jutaton. Kebutuhan jagung untuk konsumsi langsung pertahun adalah $1,56 \mathrm{~kg} / \mathrm{kapita} / \mathrm{tahun}$ (Susenas, 2013). Proyeksi jumlah penduduk Indonesia 2010-2035 BAPPENAS pada tahun 2016 jumlahpenduduk Indonesia sebesar 259.268.079 jiwa (asumsi pertumbuhan penduduk sebesar 1,49 persen per tahun), sehingga total kebutuhan jagung untuk konsumsi langsung adalah 404.458 ton per tahun (BAPPENAS,2016).

Penyakit pada tanaman jagung merupakan salah satu yang mempengaruhi pertumbuhan dan perkembangan tanaman jagung. Salah satu penyebab rendahnya produktivitas jagung adalah karena serangan patogen penyebab penyakit, diantaranya yaitu penyakit busuk batang yang disebabkan oleh jamur Fusarium sp, Giberella sp (Munkvold, 2001).

Pengembangan

tanaman

jagung yang tahan terhadap busuk batang terus dikembangkan melalui pemuliabiakkan tanaman. Setiap varietas jagung memiliki ketahanan yang berbeda dengan varietas lain terhadap serangan hama dan penyakit. Berdasarkan sifat ketahanan tersebut tanaman jagung ada varietas yang Tahan (Resisten) Varietas Gumarrang, Surya, Bisi-1, Bisi-4, Pionir-12 dan Pionir-13, pergiliran tanaman yang bukan tanaman serealia, dan terakhir gunakan fungisida seperti Mancozeb dan Carbendazim. Namun demikian, pertumbuhan dan hasil panen varietas jagung yang tahan terhadap penyakit busuk batang yang disebabkan cendawan Fusarium sp juga dipengaruhi oleh agro klimaks pada tempat budidaya.

Penelitian pertumbuhan dan hasil panen varietas jagung Lokal dan Hibrida terhadap cendawan Fusarium sp pada lokasi budidaya setempat belum banyak dipublikasikan.

\section{METODE PENELITIAN Prosedur Penelitian}

Adapun langkah-langkah dalam melakukan penelitian ini adalah :

\section{Perbanyakan cendawan Fusarium} sp

Menyiapkan alat dan bahan yang akan digunakan. Pertama yaitu menimbang kentang sebanyak 250 gram, kupas kentang dan cuci sampai besih. setelah itu memotong kentang kecil-kecil seperti dadu. Selanjutnya, merebus kentang yang telah dicuci dan dpotong-potong dengan aquades sebanyak $1000 \mathrm{ml}$ selama 1 jam dan pertahankan volume air setelah satu jam kemudian ambil filtratnya. Memasukkan dextrose sebanyak 20 gram dan agar sebanyak 15 gram kedalam filtrat air rebusan kentang, homogenkan setelah itu sterilkan kedalam Autoklaf selama 30 menit dengan tekanan 1 ATM dan suhu $125^{\circ} \mathrm{C}$, kemudian menuangkan media PDA yang telah siap kedalam cawan petri dan tabung reaksi secara 
aseptis. Selanjutnya, mengoleskan isolat cendawan Fusarium $s p$ kedalam media PDA dan terakhir yaitu mengamatan pertumbuhan cendawan Fusarium sp.

\section{Penanaman jagung}

Sebanyak 20 butir jagung yang terdiri atas 10 butir jagung varietas Lokal dan 10 butir jagung varietas Hibrida direndam dengan hormon auksin selama 24 jam dalam suhu ruang. Biji jagung hasil rendaman selanjutnya ditanam pada media tanah yang telah dicampur dengan pupuk organik dengan perbandingan 2:1 dalam polybag dengan diameter $25 \mathrm{~cm}$. Diletakkan di kebun percobaan dengan intensitas matahari yang cukup, dengan suhu $25^{0}-27^{0} \mathrm{C}$, kelembapan 50-80\%, disiram 2 kali setiap hari dan diberi pupuk Urea yang dilakukan 3 kali pada 7-10 HST, 2830 HST, dan 40-45 HST.

\section{Infeksi cendawan Fusarium sp}

Infeksi cendawan Fusarium $s p$ dilakukan pada 45 HST. Cendawan Fusarium $s p$ di infeksikan pada daun dan melalui tanah 5 tanaman jagung varietas Lokal dan 5 tanaman jagung varietas Hibrida. Setelah pemberian perlakuan dilakukan pengamatan kelayuan daun pada 14 hari setelah infeksi, pertumbuhan jagung dan hasil panen dari setiap tanaman jagung pada 90 HST.

\section{Pengamatan setelah infeksi cendawan Fusarium sp.}

Pengamatan dilakukan pada daun yang layu setelah infeksi cendawan pada hari keempat belas setelah dilakukan infesi cendawan
Fusarium sp yang selanjutnya dilakukanpengamatan pada 90 HST yang meliputi pertumbuhan dan hasil panen tanaman jagung yang meliputi :

a. Tinggi tanaman

Tinggi tanaman jagung varietas lokal dan hibrida diukur setelah 90 HST yang dimulai dari pangkal batang sampai pucuk batang yaitu tepatnya pada ruas terakhir tanaman.

b. Berat tongkol dan kernel ditimbang setelah 90 HST atau panen langsung dari setiap tanaman jagung.

c. Berat Biji (kernel). Berat biji (kernel) ditimbang setelah dipipil.

Hasil data daun layu, pertumbuhan dan hasil panen tanaman jagung varietas lokal dan varietas hibrida yang meliputi tinggi tanaman, berat jagung (berat tongkol dan biji), berat biji (kernel), dan layu daun menggunakan analisis varian satu arah dengan taraf signifikasi 0,05 dilakukan uji Beda Nyata Jujur (BNJ).

\section{HASIL PENELITIAN}

Tinggi tanaman Jagung (Zea mays)

Hasil penelitian ini menunjukan bahwa infeksi cendawan Fusarium sp berpengaruh signifikan $(\mathrm{P}<0,05)$ terhadap tinggi tanaman jagung (Zea mays) (Gambar.1). Tinggi tanaman jagung varietas lokal yang diinfeksi cendawan Fusarium sp $(95,7 \pm 2,14$ 
$\mathrm{cm})$ signifikan $(\mathrm{P}<0.05) \quad$ lebih rendah dibandingkan tinggi tanaman jagung varietas lokal yang tidak diinfeksi cendawan Fusarium $s p$ $(97,34 \pm 1,27 \mathrm{~cm})$. Tinggi tanaman jagung varietas hibrida yang diinfeksi cendawan Fusarium $s p$ $(88,3 \pm 1,92 \mathrm{~cm})$ signifikan $(\mathrm{P}<0.05)$ lebih rendah dibandingkan tinggi tanaman jagung varietas hibrida yang tidak diinfeksi cendawan Fusarium sp $(97,2 \pm 2,28 \mathrm{~cm})$. Tinggi tanaman jagung varietas hibrida yang diinfeksi cendawan Fusarium $s p \quad(88,3 \pm 1,92 \mathrm{~cm}) \quad$ berpengaruh signifikan $(\mathrm{P}<0,05)$ lebih rendah dibandingkan dengan tanaman jagung varietas lokal yang diinfeksi cendawan Fusarium sp $(95,7 \pm 2,14$ $\mathrm{cm})$. Namun, tinggi tanaman jagung varietas hibrida yang tidak diinfeksi cendawan Fusarium sp(97,2 $\pm 2,28$ $\mathrm{cm})$ tidak berpengaruh bersignifikan dengan jagung varietas lokal yang tidak diinfeksi cendawan Fusarium $s p(97,34 \pm 1,27 \mathrm{~cm})$.

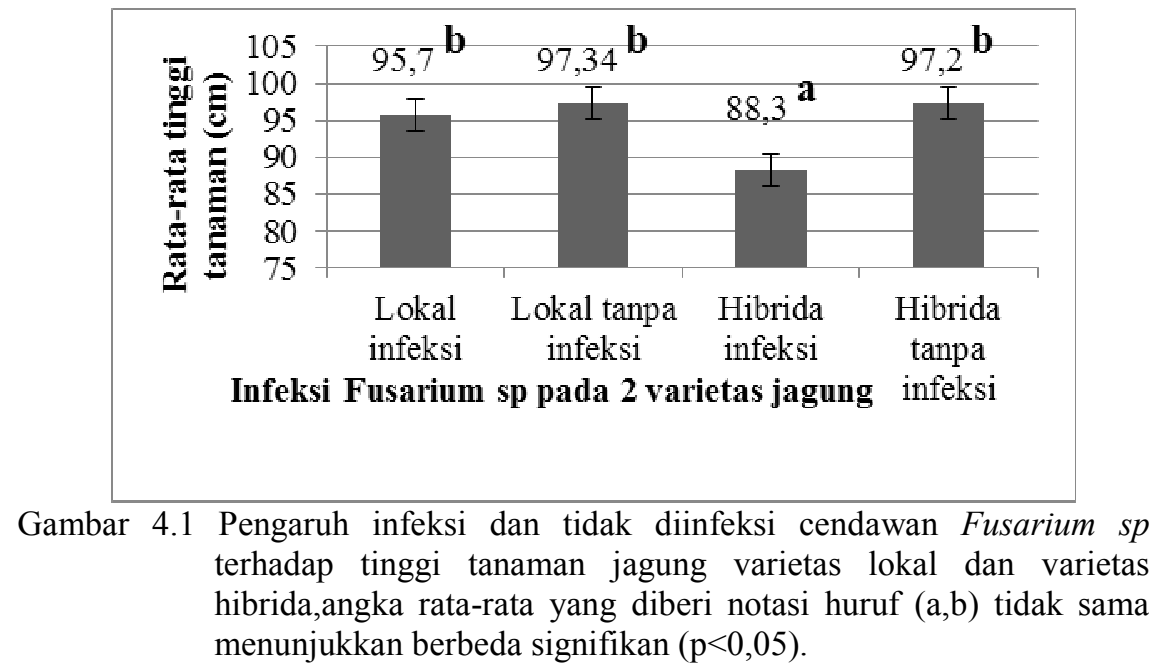

\section{Layu daun setelah infeksi}

Hasil penelitian pengaruh infeksi cendawan Fusarium sp terhadap layu daun disajikan dalam (Gambar 4.2) hasil penelitian menunjukkan bahwa infeksi cendawan Fusarium sp signifikan $(\mathrm{P}<0,05)$ terhadap kelayuan daun tanaman jagung (Zea mays).

Layu daun varietas varietas hibrida yang diinfeksi cendawan Fusarium $\quad s p \quad(5,4 \pm 0,55)$ tidak berbeda signifikan dengan layu daun pada tanaman jagung varietas hibrida yang tidak diinfeksi Fusarium $s p(5,00 \pm 0,71)$. Layu daun pada tanaman jagung varietas lokal yang tidak diinfeksi Fusarium $s p$ $(3,8 \pm 0,84)$ tidak bebeda signifikandengan layu daun tanaman jagung varietas lokal yang diinfeksi dengan cendawan Fusarium $s p$ $(4,2 \pm 0,84)$. Layu daun varietas lokal yang diinfeksi cendawan Fusarium 
$s p \quad(4,2 \pm 0,84)$ tidak berbeda tidak diinfeksi Fusarium $s p$ signifikan dengan varietas hibrida $(3,8 \pm 0,0,84)$ dengan varietas hibrida yang diinfeksi cendawan Fusarium yang tidak diinfeksi cendawan $s p(5,4 \pm 0,55)$. Serta tidak terdapat Fusarium $\operatorname{sp}(5,0 \pm 0,71)$. perbedaan yang signifikan antara layu daun antara varietas lokal yang

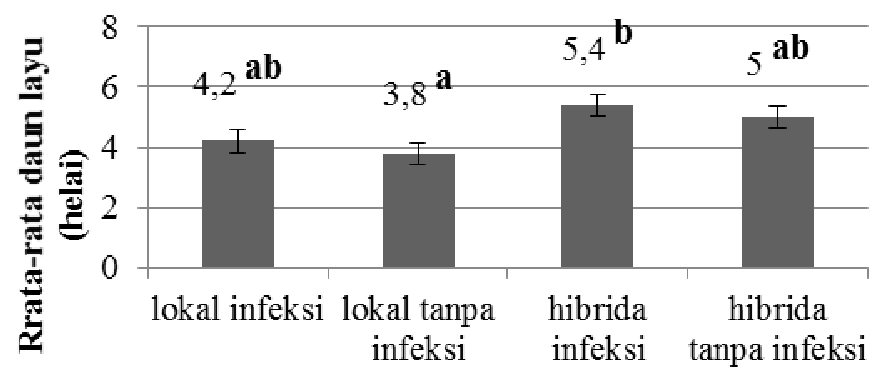

Infeksi Fusarium sp pada 2 varietas jagung

Gambar 4.2 Pengaruh infeksi dan tidak diinfeksi cendawan Fusarium sp terhadap layu daun tanaman jagung varietas lokal dan varietas hibrida, angka ratarata yang diberi notasi huruf $(a, a b, b)$ tidak sama menunjukkan berbeda signifikan $(\mathrm{p}<0,05)$.

\subsubsection{Berat jagung (tongkol+kernel)}

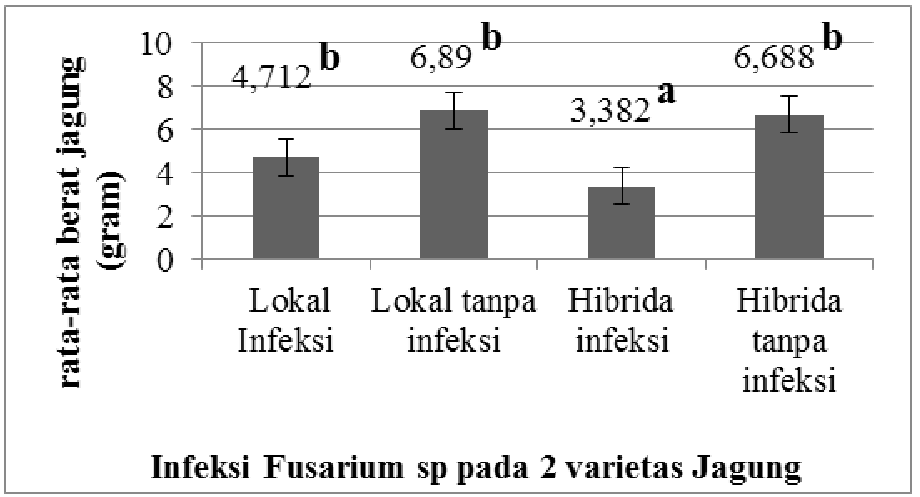

Gambar 4.3 Pengaruh infeksi dan tidak diinfeksi cendawan Fusarium sp terhadap berat jagung varietas lokal dan varietas hibrida,angka rata-rata yang diberi notasi huruf $(a, b)$ tidak sama menunjukkan berbeda signifikan $(\mathrm{p}<0,05)$.

Hasil penelitian pengaruh berat tongkol dan kernel tanaman infeksi cendawan Fusarium $s p$ berat jagung (Zea mays). Berat jagung jagung disajikan dalam (Gambar varietas lokal yang diinfeksi 4.3) hasil penelitian menunjukkan Fusarium $s p(4,712 \pm 1,84$ gram $)$ bahwa infeksi cendawan Fusarium signifikan $(\mathrm{P}<0,05)$ lebih rendah $s p$ signifikan $(\mathrm{P}<0,05)$ terhadap dibandingkan berat jagung varietas 
lokal yang tidak diinfeksi cendawan Fusarium sp $(6,89 \pm 0,60$ gram $)$ dan berat jagung varietas hibrida yang diinfeksi Fusarium sp $(3,382 \pm 0,44$ gram) signifikan $(\mathrm{P}<0,05) \quad$ lebih rendah dibandingkan tanaman jagung varietas hibrida yang tidak diinfeksi dengan cendawan Fusarium sp $(4,08 \pm 0,64$ gram). Namun berat jagung varietas lokal yang diinfeksi cendawan Fusarium $s p(4,712 \pm 1,84$ gram $)$ tidak berbeda signifikan terhadap tanaman jagung varietas Hibrida yang diinfeksi cendawan Fusarium $s p$ $(3,382 \pm 0,442$ gram)serta berat jagung varietas lokal yang tanpa diinfeksi cendawan Fusarium $s p$ $(6,89 \pm 0,67$ gram $)$ tidak berbeda signifikan terhadap tanaman jagung varietas Hibrida yang tanpa diinfeksi cendawan Fusarium $s p$ $(6,68 \pm 0,801$ gram $)$.

\section{Berat Biji (Kernel)}

Hasil penelitian pengaruh infeksi cendawan Fusarium sp pada hasil berat biji (kernel) tanaman jagung disajikan dalam (Gambar 4.4). Hasil penelitian menunjukkan bahwa infeksi Fusarium $s p$ jagung berpengaruh signifikan $(\mathrm{P}<0,05)$ terhadap pada berat biji (kernel). Berat biji (kernel) tanaman jagung varietaslokal yang diinfeksi Fusarium sp $(3,06 \pm 1,09$ gram) tidak berpengaruh berpengaruh signifikan dengan berat jagung varietas lokal yang tidak diinfeksi cendawan Fusarium sp $(4,248 \pm 0,67$ gram $)$ dan Tanaman jagung varietas hibrida yang diinfeksi Fusarium $s p$ $(2,532 \pm 0,49$ gram $) \quad$ signifikan $(\mathrm{P}<0,05)$ lebih rendah dibandingkan tanaman jagung varietas hibrida yang tidak diinfeksi dengan cendawan Fusarium sp $(4,13 \pm 0,66$ gram). Berat kernel tanaman jagung varietas lokal yang diinfeksi cendawan Fusarium sp $(3,06 \pm 1,09$ gram) tidak berbeda signifikan terhadap tanaman jagung varietas Hibrida yang diinfeksi cendawan Fusarium sp (2,532 $\pm 0,49$ gram). Berat kernel tanaman jagung varietas lokal yang tanpa diinfeksi cendawan Fusarium sp $(4,248 \pm 0,67$ gram) tidak berbeda signifikan terhadap tanaman jagung varietas Hibrida yang tanpa diinfeksi cendawan Fusarium sp $(4,13 \pm 0,66$ gram). 


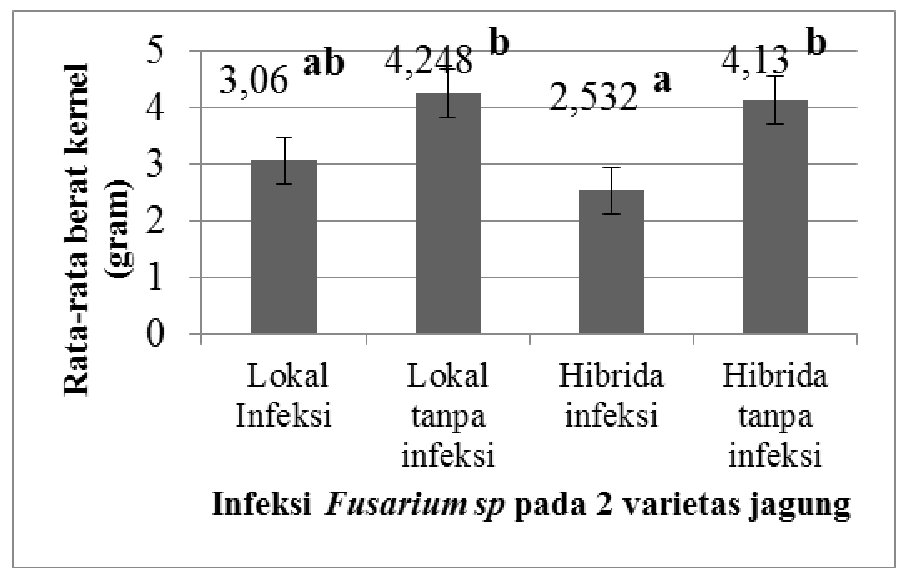

Gambar 4.4 Pengaruh infeksi dan tidak diinfeksi cendawan Fusarium sp terhadap berat kernel jagung varietas lokal dan varietas hibrida,angka rata-rata yang diberi notasi huruf $(a, a b, b)$ tidak sama menunjukkan berbeda signifikan $(\mathrm{p}<0,05)$.

\section{PEMBAHASAN}

Hasil penelitianmengindeksi bahwa infeksi cendawan Fusarium $s p$ bepengaruh signigikan terhadap pertumbuhan dan hasil panen tanaman jagung varietas lokal dan varietas hibrida. Data hasil penelitian menunjukkan bahwa infeksi yang dilakukan berpengaruh terhadap tinggi tanaman jagung. Dalam penelitian ini tinggi tanaman rat-rata hampir sama jika dilihat dari pertumbuhannya secara langsung dan infeksi cendawan Fusarium $s p$ tidak mempengaruhi tinggi tanaman jagung varietas lokal dan varietas hibrida. Hal ini terjadi karena infeksi atau perlakuan dilakukan pada 45 HST yaitu pada tahap generatif atau masa bunga jantan muncul. Menurut McWilliams, et. al., (1999) dalam Subekti et. al., (2012) pertumbuhan jagung melewati beberapa fase. Pada fase Tasseling atau masa pembungaan dimulai 2-3 hari sebelum rambut tongkol muncul, Pada fase tasseling biasanya berkisar antara 45-52 hari, ditandai oleh adanya cabang terakhir dari bunga jantan sebelum kemunculan bunga betina (silk/rambut tongkol), di mana pada periode ini tinggi tanaman hampir mencapai maksimum dan mulai menyebarkan serbuk sari (pollen). Pertumbuhan tinggi dari tanaman jagung varietas lokal lebih tinggi dari pada varietas hibrida karena adanya faktor-faktor tertentu, yaitu lokasi penelitian yang kurang mendukung pertumbuhan tanaman jagung. Kuruseng (2009) yang menyatakan bahwa pertumbuhan masing-masing varietas menunjukkan perbedaan, hal ini diduga karena perbedaan sifat 
genetik dan lingkungan tumbuh, perbedaan penampilan dari masingmasing varietas hibrida disebabkan pengaruh genetik dan lingkungan. Di mana pengaruh genetik merupakan pengaruh keturunan yang dimiliki oleh setiap varietas sedangkan pengaruh lingkungan merupakan pengaruh yang ditimbulkan oleh habitat dan kondisi lingkungan. Jika serangan cendawan Fusarium $s p$ terjadi sebelum fase generatif, maka akan mempengaruhi tinggi tanaman jagung. Sesuai dengan pendapat ploetz et al.(2003) bahwa cendawan Fusarium sp dapat mempengaruhi pertumbuhan inang,terutama pertumbuhan daun. Hal ini sesuai dengan pendapat fitriarini (2007) yang menyatakan bahwa tingginya intensitas penyakit karena cendawan Fusarium $s p$ menjadi faktor prnghambat bagi pertumbuhan tanaman yang menyebabkan rendahnya tinggi tanaman.

Hasil penelitian ini mengindikasikan bahwa infeksi cendawan Fusarium $s p$ yang dilakukan pada tanaman jagung varietas lokal dan varietas hibrida mempengaruhi pertumbuhan daun, sehingga daun mengalami kelayuan. Layu daun berawal dari daun yang tua atau berada pada pangkal batang dan berlanjut ke bagian daun yang lebih muda. Daun yang layu berwarna kuning kecokelatan dan mengering tetapi tetap menempel pada tanaman. De Cal, et al. (2000) menyatakan jamur ini menyerang jaringan bagian vaskuler dan mengakibatkan kelayuan pada tanaman inangnya dengan cara menghambat aliran air pada jaringan xilem. Jaringan xilem ini jaringan yang berfungsi untuk mengangkut air dan mineral-mineral yang terkandung dalam tanah untuk diedarkan keseluruh bagian tumbuhan yaitu salah satunya daun, jika jaringan xilem dihambat oleh cendawan Fusarium $s p$ maka proses fotosintesis juga akan terhambat. Selanjutnya dikemukakan bahwa terjadinya kelayuan akan menghentikan semua transportasi hara ke biji, sehingga dapat mempengaruhi berat biji. Proses kelayuan yang terjadi pada daun tanaman jagung varietas lokal dan varietas hibrida yang telah diinfeksi cendawan Fusarium sp bisaterjadi diduga karena adanya toksin yang terkandung dalam cendawan Fusarium sp, hal ini didukung dengan pernyataan terjadinya kelayuan akibat Fusarium oxysporum terdapat beberapa teori, yaitu teori penyumbatan, toksin, dan enzim.Teori toksin menyatakan bahwa toksin yang dihasilkan oleh Fusarium oxysporum, adalah asam fusarat, dehidrofusarat, dan likomarasmin (Sastrahidayat, 1990). Burgess et al. (2001) menambahkan bahwa Fusarium oxysporum menghasilkan enniatins, asam fusarat, moniliformin, nafthazarrins, dan sambutoksin, tetapi tidak menghasilkan fusarins, fusarokhromanon, serta fusaproliferin, dan yang paling penting adalah mikotoksin, 
fumonisins, trokhothesen, dan zearalenon. Sastrahidayat (1990) toksin tersebut akan mengubah kelenturan selaput plasma tanaman, sehingga tanaman yang terinfeksi lebih cepat kehilangan air dari pada tanaman sehat.

Pada tanaman jagung varietas lokal dan varietas hibrida yang tidak diinfeksi dengan cendawan Fusarium $s p$ mengalami layu daun lebih rendah dibandingkan varietas yang diinfeksi cendawan Fusarium $s p$. diduga infeksi yang dilakukan pada varietas lokal dan hibrida mempengaruhi layu daun pada varietas lokal dan hibrida yang tidak diinfeksi cendawan Fusarium sp. Hal ini didukung oleh Kaiser et al. (1997) menyatakan, bahwa patogen penyebab busuk batang memproduksi konidia pada permukaan tanaman inang dan dapat disebarkan oleh angin, air hujan, manusia atau pun serangga.

Hasil penelitian ini mengindikasikan infeksi cendawan Fusarium $s p$ juga mempengaruhi berat jagung (berattongkoldanbiji) dan beratbiji (kernel) varietas lokal dan varietas hibrida, hal ini terjadi karena serangan yang ditimbulkan dari cendawan patogen Fusarium sp adalah daun mengalami kelayuan. Oleh karena itu fungsi dari daun yaitu bagian jaringan vaskular pada pembuluh xilem yang membawa air dan nutrisi terlarut dari dalam tanah untuk pertumbuhan dan perkembangan tanaman menjadi terhambat. Layu daun yang terjadi pada hari ke-14 setelah infeksi dan pada saat tanaman jagung pada fase R2 (blister) muncul sekitar 10-14 hari setelah silking yaitu proses setelah penyerbukan terjadi dan pada fase ini pembentukan tongkol hampir sempurna dan biji mulai nampak. Hal tersebut diduga bahwa infeksi cendawan Fusarium $s p$ mempengaruhi berat jagung. Sesuai yang dikemukakan oleh Munkvold, et al. (1997) bahwa cendawan ini dapat menginfeksi tanaman jagung pada semua fase perkembangan sejak menginfeksi biji, melalui luka gigitan serangga vektor dan sumber inokulum, kemudian menginfeksi pada fase prapanen hingga pascapanen. Rendahnya berat biji (kernel) perlakuan cendawan Fusarium $s p$ memberikan petunjuk bahwa patogen Fusarium sp mampu menghambat asupan unsur hara tanaman jagung sehingga kebutuhan nutrisi untuk pertumbuhan dan perkembangan tidak disuplai dengan baik dari dalam tanah. Hal ini didukung oleh Kaiser et al. (1997), yang menyatakan bahwa tanaman jagung terserang patogen Fusarium $s p$ tampak layu seluruh daun mengering dan gejala tersebut umumnya terjadi pada stadia generatif, yaitu setelah fase pembungaan.

\section{KESIMPULAN}

Perlakuan infeksi cendawan Fusarium $s p$ pada tanaman jagung dapat menurunkan pertumbuhan dan hasil panen tanaman jagung ( $\mathrm{Zea}$ mays) varietas lokal dan varietas hibrida. 
Pertumbuhan dan hasil panen tanaman jagung (Zea mays) varietas lokal lebih tinggi dibandingkan tanaman jagung varietas hibrida yang diinfeksi cendawan Fusarium $s p$.

\section{SARAN}

Hasil penelitian ini dapat dijadikan referensi untuk para petani tanaman jagung pada musim kemarau untuk menanam jagung varietas lokal, karena tanaman jagung varietas lokal lebih resisten terhadap penyakit busuk batang akibat serangan cendawan Fusarium $s p$ dibandingkan tanaman jagung varietas hibrida.

\section{DAFTAR PUSTAKA}

Adisarwanto dan Widyastuti. 2000. Teknik Bertanam Jagung. Kanisius.Yogyakarta.

Balitserealia. 2010. Jagung Hibrida Unggul Nasional, 2010: 6 10.

De Cal A, Garcia-Lepe R \& Melgarejo P. 2000. Induced resistance by Penicillium oxalicumagainst $F$. oxysporum f.sp.lycopersici: Histological studies of infected and inducedtomato stem. Phytopathology 90: 260-268.

Kaiser, A., J. Colles, J. Lawson, and C. Nicholls. 1997. Australian Maize. Kondinin Group. 144 p.

Munkvold, G.P. and W.M. Carlton. 1997. Influence of inoculation method on systemic Fusarium moniliforme infection of maize plants grown from infected seed. Plant Disease 81(2):211-216.

Suarni, dan S. Widowati. 2012. Struktur, komposisi, dan nutrisi jagung. Prosiding Seminar dan Lokakarya Nasional Jagung. Makassar : 410-426.

Syafruddin. 2002. Tolok ukur dan konsentrasi Al untuk penapisan tanaman jagung terhadap ketenggangan Al. Berita Puslitbangtan 24: 3-4. 